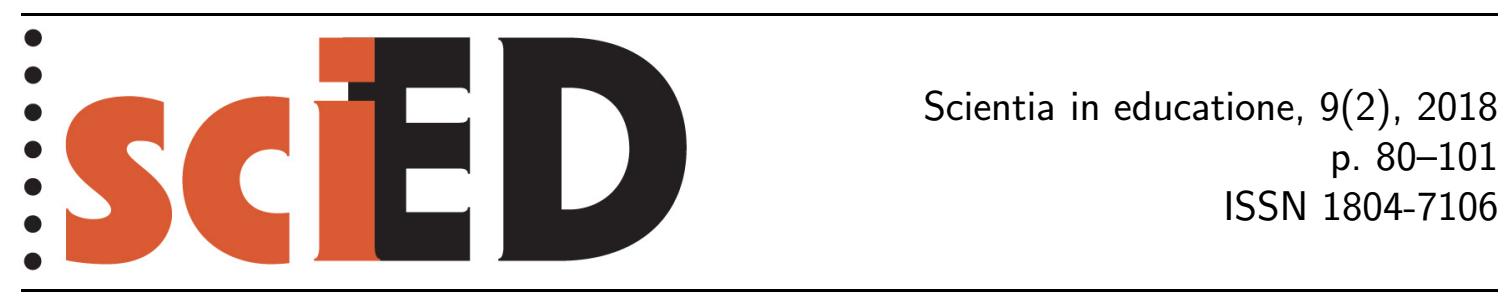

\title{
Možnosti využití škály MSELS pro testování environmentální gramotnosti na základních školách v České republice
}

\author{
Silvie Svobodová, Roman Kroufek
}

\begin{abstract}
Abstrakt
Příspěvek prezentuje výsledky verifikace využitelnosti výzkumného nástroje MSELS ( $M i$ ddle School Environmental Literacy Survey) na základních školách v Ceské republice. Testovány byly vybrané psychometrické vlastnosti škály jako celku i jejích jednotlivých segmentů. Zjištění byla konfrontována s výsledky prvního použití nástroje při národním výzkumu environmentální gramotnosti v USA (McBeth \& Volk, 2010; McBeth et al., 2011), který probíhal u žáků šestých a osmých tříd. Cílovou skupinou výzkumu představovaného v tomto př́spěvku byli žáci 6 . -9 . tříd základních škol v regionu Žatec. Důkazy pro validitu interpretace získaných dat byly hledány ve všech oblastech doporučovaných Standardy pro pedagogické a psychologické testování (AERA, APA \& NCME, 2014). Ve většině případů se podařilo předložit uspokojivý soubor dokladů, které podporují využití škály u žáků druhého stupně ZŠ. Reliabilita škál Postoje, Jednání a Senzitivita dokládaná koeficienty jejich vnitřní konzistence dosáhla akceptovatelných hodnot $(\alpha>0,75)$ a tyto škály je možné doporučit pro realizaci výzkumů. U škály Znalosti byla zjištěna nízká reliabilita $(\alpha=0,55)$. Její aplikace je možná, avšak zjištěná data musí být vzhledem k reliabilitě interpretována obezřetně.
\end{abstract}

Klíčová slova: environmentální gramotnost, MSELS, žáci, základní školy, Česká republika.

\section{Possibilities of Using the MSELS Scale for Environmental Literacy Testing in Czech Primary Schools}

\begin{abstract}
The paper presents the results of an experiment which sought to verify the usability of the MSELS (Middle School Environmental Literacy Survey) research tool in Czech primary schools. Selected psychometric properties of the scale were tested as a complex unit and also within individual segments. The findings were compared with the results of the first usage of the tool during a nationwide research of environmental literacy performed in the USA (McBeth \& Volk, 2010; McBeth et al., 2011), which involved sixth- and eighthgraders. The target group for the research presented in this paper were pupils in sixth
\end{abstract}


through ninth grades attending primary schools in the Žatec region. Evidence for the validity of the interpretation of the data obtained was discussed in all areas recommended by the Standards of Educational and Psychological Testing (AERA, APA \& NCME, 2014). In most cases, a satisfactory set of evidence was produced to support the use of the scale for the benefit of pupils attending $5^{\text {th }}-8^{\text {th }}$ grades of a primary school. The reliability of the attitude scales, actions and sensitivity, documented by the coefficients of their internal consistency, was within acceptable values $(\alpha>0.75)$, which is why the scales may be recommended for conducting research. The knowledge scale, on the other hand, indicated low reliability $(\alpha=0.55)$. Its applicability is still possible, yet the data must be interpreted carefully with respect to their reliability.

Key words: environmental literacy, MSELS, pupils, primary school, Czech Republic.

Cílem př́íspěvku je ověření, psychometrických parametrů reliability a validity, a zároveň tedy využitelnosti, zahraničního výzkumného nástroje MSELS - Middle School Environmental Literacy Survey (McBeth \& Volk, 2010), resp. verze, kterou přeložili a modifikovali autoři článku, k testování environmentální gramotnosti žáků druhého stupně základní školy v českém prostředí.

$\mathrm{V}$ současnosti se můžeme setkat $\mathrm{s}$ několika více či méně odlišnými přístupy ke konceptu environmentální gramotnosti. V 90. letech 20. století bylo odborníky aktivně přijímáno a v mnoha výzkumech často aplikováno pojetí, při jehož definování vychází Roth (1992) zejména z cílů environmentální výchovy vymezených na konferenci v Tbilisi (UNESCO, 1977). Jeho multidimenzionální koncepci potvrdili a shrnuli do čtyř dimenzí (kognitivní; afektivní; přesvědčení o vlastním vlivu a osobní odpovědnosti; osobní a skupinové zapojení v environmentálně odpovědném jednání) Hungerford et al. (1994).

Od konce 20. století byly v průběhu několika let NAAEE (Severoamerická asociace environmentální výchovy) nadefinovány doporučující standardy vymezující cílové oblasti environmentální výchovy na základě hledání konsensu v týmu odborných expertů (NAAEE, 2010). Stanovené standardy koncipované do čtyř hlavních oblastí (badatelské dovednosti ve vztahu k environmentálním tématům; znalosti environmentálních procesů a systémů; dovednosti pro identifikaci a řešení environmentálních problémů; osobní a občanská odpovědnost) se staly východiskem k výzkumy podloženému vymezení environmentální gramotnosti (Hollweg et al., 2011) za účelem jejího testování v rámci mezinárodního šetření PISA 2015 (Daniš, 2013), což ovšem nebylo realizováno. S uvedenými zásadami NAAEE pro excelentní environmentální výchovu pracuje také NÚV (Národní ústav pro vzdělávání) při reflexi environmentální výchovy jako průřezového tématu (NÚV, 2018).

Environmentální gramotnost je v současné době vnímána jako koncept komplexně pojímající všechny rámcové cíle environmentální výchovy (Hollweg et al., 2011), český překlad uvedl Daniš (2013). Definice vychází z dlouhodobě akceptovaného dělení environmentální gramotnosti do jednotlivých dimenzí, kdy je každá z nich charakterizována výčtem samostatně měřitelných složek, jejichž vzájemný vztah není jednoznačný. Environmentální gramotnost lze tedy chápat jako komplex následujících dimenzí: znalosti (kognitivní dimenze), dispozice (afektivní dimenze), kompetence a environmentálně odpovědné jednání (konativní dimenze) (Kroufek, 2016). 
Autoři článku se ztotožňují s definicí vycházející ze standardů NAAEE (Hollweg et al., 2011), protože nejkomplexněji pojímá všechny oblasti environmentální gramotnosti. Nedoporučují ovšem používání Danišem (2013) zavedeného pojmu dispozice pro afektivní dimenzi, pracuje s ním i jiná pedagogická a psychologická literatura a mohl by být mylně interpretován.

V zahraničí se na výzkumy studentů ve věku odpovídajícímu žákům druhého stupně základní školy zaměřili například Jeffries et al. (2001), Bronven et al. (2004), Andrews et al. (2008), Penuel et al. (2006) či Gul a Yesilyurt (2011), kteří se orientovali zejména na environmentální znalosti a s nimi spojené miskoncepty. Naopak na environmentální senzitivitu se soustředila Bragg et al. (2013), van Petegem a Blieck (2006) se zase věnovali evaluaci programů environmentální výchovy pro žáky základních škol v Belgii a Zimbabwe.

V ČR bylo v rámci testování environmentální gramotnosti žáků druhého stupně základní školy realizováno několik výzkumů. Ze studií cílených na žáky základních a studenty středních škol lze uvést např. výzkumy Kulicha a Dobiášové (2003), Bezoušky a Činčery (2007), Činčery a Štěpánka (2007), Schovajsové (2010), Hromádky (2010), Vacínové a Matějčka (2013) a Svobodové (2013; 2016), které jsou charakteristické komplexním pojetím, tj. analýzou kombinace několika dimenzí environmentální gramotnosti, a využitím zahraničních nástrojů. Autoři se věnovali nejenom testování jednotlivých dimenzí, ale také vztahu mezi nimi a vlivu konkrétních proměnných, např. demografických či profilace školy.

Mezi nejznámější analytické nástroje vhodné pro komplexní měření environmentální gramotnosti patří MSELS (McBeth \& Volk, 2010), který byl vyvinut ve Spojených státech amerických. Jedná se o nástroj orientovaný na žáky ve věku odpovídajícím zhruba druhému stupni základních škol. Je složen ze škál zaměřených na zjištování environmentálních znalostí, postojů, senzitivity, dovedností k analýze a následnému efektivnímu řešení environmentálních problémů. V letech 2007-2009 byl v USA s využitím MSELS realizován národní výzkum environmentální gramotnosti žáků šestých a osmých tříd, první a následně druhá srovnávací fáze (McBeth \& Volk, 2010; McBeth et al., 2011). Nástroj složený ze 75 položek s možností výběru odpovědí byl navržen tak, aby jeho administrace trvala max. 50 minut.

V Ceské republice nebyl dosud tento nástroj testován v plném rozsahu, někteří výzkumníci použili pouze některé škály a kombinovali je s jinými nástroji. Vybraná část nástroje zaměřená na porozumění ekologickým konceptům, tj. environmentální znalosti, které jsou zjištovány jednoduchým testem se 17 položkami, v nichž respondent vybírá vždy pouze jednu správnou odpověd' ze čtyř možností, byla přeložena a ověřena na žácích pátého ročníku základní školy (Schovajsová, 2010). Testování modifikované škály prokázalo poměrně nízkou náročnost testu pro starší respondenty, nicméně výsledky ukázaly, že se jedná o nástroj akceptovatelný z hlediska reliability $(\alpha=0,63)$ (Činčera, 2013).

V rámci prezentované výzkumné sondy bude testována využitelnost, validita a reliabilita zahraničního výzkumného nástroje MSELS pro zjištování kognitivní, afektivní a konativní dimenze environmentální gramotnosti žáků druhého stupně základní školy v České republice.

\section{Metodologie}

Šetření zaměřené na testování využitelnosti výzkumného nástroje MSELS k měření environmentální gramotnosti žáků bylo realizováno na základních školách re- 
gionu Žatec. Zařazeny byly tyto školy: ZŠ Žatec, nám. 28. ř́jna 1019, okres Louny $(N=96)$, Základní škola Žatec, Komenského alej 749 , okres Louny $(N=195)$ a ZŠS Měcholupy, okres Louny $(N=53)$. Respondenty byli žáci 6 . až 9 . ročníků druhého stupně $(N=344)$, a to 182 dívek a 162 chlapců.

Žatecko představuje druhou nejřidčeji osídlenou oblast Ústeckého kraje (ČSÚ, 2018a). S ohledem na demografické a socioekonomické ukazatele lze konstatovat, že se nejedná o zcela typický region ČR. Aktuální podíl ekonomicky aktivních obyvatel v regionu je sice zhruba stejný jako v ČR a výrazně se neliší ani současná míra nezaměstnanosti (ČSÚ, 2018b; 2018c), ovšem z dlouhodobého hlediska se Žatecko řadí k oblastem s vyšší koncentrací sociálně slabšího obyvatelstva nízké vzdělanostní úrovně a vyšší nezaměstnaností (KÚ Ústeckého kraje, 2011). V Žatci jsou evidovány tři sociálně vyloučené lokality (MPSV, 2015).

Ústecký kraj se v současnosti řadí k regionům s nejhoršími výsledky přijímacího řízení na střední školy (CERMAT, 2017). Žáci 5. a 9. tříd v kraji znatelně zaostávají ve vědomostech (ČŠI, 2017). V rámci mezinárodního šetření PISA 2015 dosáhli v př́rodovědné gramotnosti patnáctiletí žáci druhého nejslabšího výsledku ve srovnání s ostatními kraji, přičemž se jednalo o výrazně nižší úroveň, než které by měli docílit podle indexu ekonomického, sociálního a kulturního statusu (ESCS) (Blažek \& Př́hodová, 2016).

Základní školy zařazené do testování lze považovat za školy běžného typu, přičemž ZŠ Měcholupy představuje školu vesnického typu s nízkým počtem žáků, další dvě reprezentují školy městské. Z inspekčních zpráv ČŠI vyplývá, že se jedná o školy, které poskytují kvalitní vzdělávání a jeho průběh dosahuje očekávané úrovně (ČŠI, 2018).

Vzhledem k výše uvedenému lze očekávat, že žáci v našem výzkumu mohou dosahovat nižší úrovně znalostí a dovedností, která je významně podmíněna také sociokulturním rodinným zázemím, než jaká by odpovídala reprezentativnímu vzorku v rámci celé ČR.

Výzkumný nástroj MSELS, Middle School Environmental Literacy Survey (McBeth \& Volk, 2010) byl přeložen a upraven, aby reflektoval společenské a sociální prostředí cílové skupiny. Modifikovaná verze nástroje MSELS (viz př́loha 1) představuje dotazník s 59 položkami rozdělenými do šesti segmentů.

První segment je tvořen položkami identifikujícími žákův demografický background. Následujících sedmnáct položek vždy s jednou správnou odpovědí ze čtyř možností je zaměřeno na environmentální znalosti, a jedná se tedy o didaktický test. V třetím segmentu jsou zjištovány environmentální postoje, ve čtvrtém je odhalováno environmentální jednání, pátý segment je orientován na environmentální senzitivitu a dvě závěrečné položky analyzují vztah žáka k přírodě a životnímu prostředí. Míru souhlasu u těchto položek vyjadřovali respondenti na pětibodové Likertově stupnici (Chytrý \& Kroufek, 2017). Jednotlivé odpovědi byly bodovány hodnotami 5 (souhlasím, velmi silný, velmi často, zcela souhlasím) až 1 (nesouhlasím, minimální, nikdy a zcela nesouhlasím). Položky reprezentující odklon od pozitivně environmentálního pojetí byly bodovány reverzně.

Testování normality dat proběhlo pomocí Shapiro-Wilkova testu normality (Shapiro \& Wilk, 1965). Byla zjištována pro škály Postoje, Jednání a Senzitivita, protože proměnná zjištovaná těmito škálami má spojitý charakter.

Důkazy pro validitu interpretace výsledků testu byly podány v souladu se Standardy pro pedagogické a psychologické testování (AERA, APA \& NCME, 2014). $\mathrm{V}$ rámci tohoto přístupu k validitě je vhodné podávat její doklady pro každé použití výzkumného nástroje v odlišném kontextu, tedy např́iklad pro didaktické testování, 
srovnávací studii, evaluaci apod. „Validita tedy poukazuje na to, do jaké míry důkazy a teorie podporují interpretace výsledků pro navrhované využití testu." (AERA, APA \& NCME, 2014: s. 11). Neprobíhá tedy validizace testu, ale spíše jeho využití pro specifický záměr. $\mathrm{V}$ našem případě je tímto záměrem testování environmentální gramotnosti žáků 2. stupně základní školy v České republice. Postupně byly hledány doklady ve všech pěti oblastech validity, tedy doklady založené na obsahu výzkumného nástroje, na jeho vnitřní struktuře, na vztahu získaných dat $\mathrm{k}$ dalším proměnným, na důsledcích testování a konečně na reakci respondentů na daný nástroj.

Reliabilita položek, na které se odpovídá na pětibodové Likertově stupnici, byla zjištována výpočtem koeficientu Cronbachova alfa (Cronbach, 1951), u škály Znalosti pak byl využit Kuder-Richardsonův vzorec 20 (Kuder \& Richardson, 1937), který je vhodný pro položky s dichotomickým pojetím výsledků. U všech škál byla zjištována také Split-Half reliabilita, a to pomocí deseti náhodných výběrů a jejich následného zprůměrování.

Pro škálu Znalosti, která má charakter didaktického testu, byl dále zjištován index obtížnosti $P$ a koeficient citlivosti ULI (Škoda \& Doulík, 2007).

\section{VÝSLEDKY}

Výsledky testování normality rozložení získaných dat jsou uvedeny v tab. 1. Ve všech třech př́padech odmítáme nulovou hypotézu o normálním rozložení dat. Vzhledem $\mathrm{k}$ velikosti výběrového souboru by bylo možné využít také metody parametrické (Mareš, Rabušic \& Soukup, 2015).

Tab. 1: Normalita jednotlivých škál nástroje MSELS

\begin{tabular}{l|l} 
Škála & Shapiro-Wilk \\
\hline Postoje & $W=0,987 ; p=0,001$ \\
Jednání & $W=0,992 ; p=0,049$ \\
Senzitivita & $W=0,991 ; p=0,028$ \\
\hline
\end{tabular}

$W$ - výsledek Shapiro-Wilkova testu normality; hodnoty $p<0,05$ jsou statisticky významné na $5 \%$ hladině významnosti

Doklady pro validitu jsou dle preferovaného přístupu členěny do několika okruhů (AERA, APA \& NCME, 2014), které více či méně korespondují s klasickým členěním validity (Hendl, 2015).

Důkaz validity založený na obsahu výzkumného nástroje řeší vztah jeho obsahu k platnému pojetí konstruktu, který má měřit, případně k dalším relevantním zdrojům (Sireci \& Faulkner-Bond, 2014). Pomocí nástroje MSELS je v tomto výzkumu zjištována environmentální gramotnost žáků 2. stupně základní školy. Autory používaná, výzkumy podložená definice environmentální gramotnosti (Hollweg et al., 2011) sestává ze tř́i dimenzí, které dohromady tvoří tuto gramotnost. Je proto namístě po obdobné struktuře pátrat u výzkumného nástroje, který navíc vznikl dřive než zmíněná definice konstruktu. Dimenze afektivní je v MSELS zastoupena hned třikrát, a to v segmentech Environmentální postoje, Environmentální senzitivita a Vztah k životnímu prostředí. Dimenze kognitivní je reprezentována segmentem Environmentální znalosti. Dimenze konativní v MSELS figuruje jednak u segmentu Environmentální jednání, jednak v segmentu Environmentální postoje, jehož položky často směřují k jednání zamýšlenému, potenciálně realizovatelnému. 
U škály Environmentální znalosti je vhodné její obsah zasadit také do kontextu platných kurikulárních dokumentů. V rámci závazného kurikula obsah této škály koresponduje jednak s obsahem segmentu Základy ekologie vzdělávacího oboru Přírodopis (vzdělávací oblast Člověk a příroda), jednak s tematickým okruhem Základní podmínky života průřezového tématu Environmentální výchova (MŠMT, 2017). Významná shoda je také s klíčovým tématem Zákonitosti, které je rozpracováno v Doporučených očekávaných výstupech pro environmentální výchovu (Pastorová, 2011). Didaktický test, který je součástí MSELS, tak plně respektuje současné kurikulární dokumenty.

Nástroj byl jako celek posouzen odborníkem z oblasti environmentální výchovy a vyhodnocen z hlediska vztahu obsahu k řešenému konstruktu jako relevantní.

Doklad validity založený na vnitřni struktuře výzkumného nástroje sestává z několika aspektů (Rios \& Wells, 2014), z nichž bude testována reliabilita nástroje.

Výsledky testů reliability počítané pro jednotlivé škály nástroje MSELS jsou uvedeny v tab. 2 a byly doplněny o hodnoty získané tvůrci originálního testu (McBeth et al., 2008).

Tab. 2: Reliabilita jednotlivých škál nástroje MSELS

\begin{tabular}{l|ccc}
\hline Skála & $\begin{array}{c}\text { Cronbachova } \alpha / \\
\text { Kuder-Richardson } 20\end{array}$ & Split-Half & $\begin{array}{c}\text { Originál } \\
\text { (McBeth et al., 2008) }\end{array}$ \\
\hline Znalosti & 0,55 & 0,50 & 0,79 \\
Postoje & 0,76 & 0,75 & 0,84 \\
Jednání & 0,75 & 0,82 & 0,78 \\
Senzitivita & 0,79 & 0,78 & 0,76 \\
\hline
\end{tabular}

Hodnoty reliability $\alpha$ se nachází v intervalu $\langle 0 ; 1\rangle, \alpha>0,7=$ dostatečná reliabilita

Při předkládání důkazu validity založeném na vztahu $k$ dalším proměnným je možné využít dva odlišné designy, predikční a souběžný (AERA, APA \& NCME, 2014). První určuje, zda výsledky testu předpovídají budoucí hodnoty nějakého jiného kritéria, druhý pak pracuje s informacemi získanými ve stejném čase, v jakém je test administrován. V př́padě využitého testu není možné vzhledem k jeho nastavení a již proběhlé administraci takové důkazy doložit. Relevantní je pouze hledat pomocí souběžného designu doklady pro validitu škály Jednání. Výsledky pomocí ní získané středně silně kladně korelují s výsledky škál Postoje $(\rho=0,59)$ a Senzitivita $(\rho=0,52)$. Afektivní složky environmentální gramotnosti tak pravděpodobně pozitivně ovlivňují složku konativní. V př́padě složky kognitivní takový vztah nalezen nebyl $(\rho=0,08)$.

Relativně novým přístupem je předkládání důkazů validity založených na $d{ }^{-}$ sledcích testování (Sireci \& Padilla, 2014). Jak upozorňuje Laneová (2014), význam těchto důkazů variuje $\mathrm{v}$ závislosti na společenské závažnosti testu a jeho možných dopadi̊. V př́ipadě využití MSELS k zjištování environmentální gramotnosti žáků druhého stupně českých základních škol jsou rizika důsledků spíše nízká. Mezi pozitivní dopady lze počítat jednak příspěvek na poli základního výzkumu, kdy získaná data umožní zasadit sledovanou populaci do mezinárodního kontextu, a jednak se pedagogům a dalším realizátorům environmentální výchovy dostává do ruky nástroj, kterým je možné evaluovat dosažení výsledků jejich práce. Takové nástroje komplexního rázu zatím pro české poměry spíše chybějí (Činčera, 2013). Negativní dopady mohou být spatřovány v možném srovnávání jednotlivých základních škol či regionů, které může mít potenciálně negativní konotaci. 
Posledními z důkazů validity jsou důkazy založené na reakci respondentů na daný nástroj. V zásadě se jedná o doklady, které zohledňují způsoby, jakými jsou data od respondentů získávána a jak je toto získávání ovlivněno variabilitou respondentů a tazatelů. Vzhledem ke způsobu administrace nástroje je míra vlivu tazatelů nízká, nástroj je administrován coby papírový dotazník, do jeho vyplňování respondenty tazatelé nijak nezasahují. Doklady validity založené na reakci respondentů úzce souvisí s doklady založenými na obsahu výzkumného nástroje, protože proces odpovídání na jednotlivé položky významně ovlivňuje jejich stavba a srozumitelnost. Ta může být odlišná pro respondenty $\mathrm{z}$ odlišných skupin, $\mathrm{v}$ případě této studie především těch založených na věku. Tato problematika byla uchopena v rámci předvýzkumu, kdy byl český překlad konzultován s nezávislým odborníkem se zkušenostmi s evaluací programů environmentální výchovy. Dále byly jednotlivé položky předkládány žákům různého věku (12-15 let), kteři připomínkovali jejich srozumitelnost. Na základě připomínek z obou těchto zdrojů byly následně položky dotazníku upraveny do současné podoby.

Pro škálu měřící znalosti, tedy didaktický test, byl dále určen index obtížnosti, který v př́ipadě celého testu činil vhodných $P=61$. Při zjištování indexu obtížnosti jednotlivých testových položek bylo odhaleno šest položek velmi snadných $(p>80)$. Šlo o položky $6,7,8,12,13$ a 18 (viz česká verze testu v př́loze 1 ).

U škály Znalosti byla také zjištována citlivost jednotlivých položek, a to výpočtem koeficientu citlivosti ULI. Výsledné hodnoty $d$ oscilovaly v intervalu $\langle 0,1 ; 0,4\rangle$, přičemž nevhodný vztah mezi indexem citlivosti a indexem obtížnosti byl zjištěn u položek 9, 15 a 16 (podezřelé položky s vysokým indexem obtížnosti nebyly v tomto směru analyzovány).

\section{DiskUSE}

Byly předloženy doklady pro validitu dat získaných pomocí české verze nástroje Middle School Environmental Literacy Survey (MSELS), které, až na výjimky, podporují její využití u žáků druhého stupně základní školy.

Doklady validity založené na důsledcích testování pokládáme za dostatečné i vzhledem k tématu, který výzkumný nástroj řeší. Naopak nebylo možné relevantně předložit doklady založené na vztahu $\mathrm{k}$ dalším proměnným. Absence jedné $\mathrm{z}$ dimenzí důkazů, založené na specifičnosti administrace nástroje, v zásadě neohrožuje doklad validity jako takové (AERA, APA \& NCME, 2014).

Doklady validity založené na obsahu výzkumného nástroje a reakci respondentů na něj taktéž saturují potřeby pro jeho validní využití. Položky korespondují s aktuálním pojetím měřeného konstruktu (Hollweg et al., 2011) i s platnými kurikulárními dokumenty. S těmi se shoduje především škála Znalosti, která ale v úplné podobě vykazuje jiné problémy. Při jejich analýzách byl zjištován index obtížnosti a koeficient citlivosti, které poukázaly na problematické položky. Konkrétně č. $6,7,8,12$, 13 a 18 v př́padě obtížnosti a č. 9,15 a 16 u citlivosti. Zjištěné problémy mohou být zapřičiněny nedokonalostmi $\mathrm{v}$ překladu, které nemusely být zcela eliminovány ani konzultací s odborníkem a samotnými respondenty v rámci předvýzkumu.

Škála Znalosti vykazuje drobné problémy také v případě dokladů založených na vnitřní struktuře sledovaného nástroje. Svou reliabilitou $(\alpha=0,55)$ se od zjištění McBethové et al. (2008) výrazně liší. Hodnota reliability této škály je na samé hranici akceptovatelnosti, za přijatelnou takovou hodnotu považují Shoukri a Edge (1996), jiní autoři (Sekaran, 1992; Tavakol \& Denick, 2011) ji však pokládají za nízkou. Škála 
znalosti byla v minulosti využita v České republice jako samostatný nástroj, Činčera (2013) při jejím nasazení zjistil akceptovatelnou reliabilitu $(\alpha=0,63)$, Schovajsová (2010) se k vnitřní konzistenci nástroje nevyjadřuje. Ani v případě vypuštění položek označených indexem obtížnosti a koeficientem citlivosti jako problematické se vnitřní konzistence škály nezvýšila a hodnota reliability tedy nerostla.

Reliabilita zbývajících škál Postoje, Jednání a Senzitivita je ve všech př́ípadech $\alpha \geq 0,75$ a ve shodě s pracemi věnujícími se interpretaci koeficientu reliability (Sekaran, 1992; Shoukri \& Edge, 1996; Tavakol \& Denick, 2011) ji lze považovat za zcela akceptovatelnou. Zjištěné hodnoty (viz tab. 2) jsou také v podstatě shodné s hodnotami, ke kterým při tvorbě a prvním rozsáhlém nasazení nástroje došli McBethová et al. (2008).

McBethová et al. (2008) uvádějí reliabilitu nástroje jako celku $(\alpha=0,82)$. V našem případě by taková hodnota činila $\alpha=0,87$, ale její uvádění pokládáme přinejmenším za problematické, protože jednotlivé škály měří odlišné faktory a hodnoty Cronbachovy alfy je možné korektně interpretovat pouze u jednofaktorových škál.

Validizace je z podstaty věci nikdy nekončící proces, který je opětovně startován novým sběrem dat. Budoucí bádání by se v tomto kontextu mělo zaměřit na hlubší rozbor saturace jednotlivých faktorů u vícepoložkových škál a případnou další modifikaci škály Znalosti.

\section{LIMITY STUDIE}

Limitem této studie je způsob výběru respondentů, který je běžný v pedagogickém výzkumu, ale neodpovídá náhodnému výběru. Výzvou pro autory i čtenáře je pak pojetí validity, značně odlišné od toho, jak ji tradiční česká metodologická literatura chápe.

\section{ZÁVĚR}

V textu jsou předkládány doklady pro validitu interpretace dat získaných pomocí české verze výzkumného nástroje MSELS, který byl distribuován žákům druhého stupně základních škol v České republice.

Jako problematická se z hlediska dalšího využití jeví škála zaměřená na znalosti žáků. Ta má formát didaktického testu, dosahuje nízké reliability a také další testové vlastnosti (obtížnost, citlivost) poukazují na nefunkční položky. Použití a interpretaci znalostní škály nevylučujeme, ale upozorňujeme na nutnost zvýšené opatrnosti při interpretaci zjištěných výsledků.

Zbývající škály se reliabilitou nijak významně neliší od výsledků, ke kterým došli autoři originálu (McBeth et al., 2008), a ve všech př́padech je $\alpha>0,75$.

Doklady pro validitu podporují využití škály u cílové skupiny s obezřetným př́istupem ke škále zjištující znalosti.

\section{PoDĚKOVÁNí}

Tento článek byl podpořen interním grantem UJEP s č. UJEP-IGS-2018-43-001-1 a projektem Studentské grantové soutěže UJEP-SGS-2017-43-003-2. 


\section{LITERATURA}

AERA, APA \& NCME. (2014). Standards for educational and psychological testing. Washington, DC: American Educational Research Association.

Andrews, K.E., Tressler, K.D. \& Mintzes, J. J. (2008). Assessing environmental understanding: an application of the concept mapping strategy. Environmental Education Research, 14(5), 519-536.

Bezouška, A. \& Činčera, J. (2007). Vliv environmentální profilace středních škol na proenvironmentální postoje a jednání studentů. Envigogika, 2(3). doi: $10.14712 / 18023061.20$

Blažek, R. \& Př́hodová, S. (2016). Mezinárodni šetření PISA 2015. Národní zpráva. Př́rodovědná gramotnost. Praha: ČŠI.

Bronven, D., Stanisstreet, M. \& Boyes, E. (2004). How can we best reduce gobal waming? School students' ideas'and misconceptions. International Journal of Environmental Studies, 61(2), 211-222. doi: 10.1080/0020723032000087907

Brown, J. D. (2002). The Cronbach alpha reliability estimate. Shiken: JALT Testing \& Evaluation SIG Newsletter, 6(1), 17-18.

Bragg, R., Wood, C., Barton, J. \& Pretty, J. (2013). Measuring connection to nature in children aged8-12: A robust methodology for the RSPB. University of Essex.

CERMAT. (2017). Jednotná přijímací zkouška 2017. Analýza uchazečů o studium na SS̆ a jejich výsledky. Praha: CERMAT.

Cronbach, L. J. (1951). Coefficient Alpha and the internal structure of tests. Psychometrika, 16(3), 297-334.

Činčera, J. \& Štěpánek, P. (2007). Výzkum ekologické gramotnosti studentů středních odborných škol. Envigogika, 2(1). doi: 10.14712/18023061.12

Činčera, J. (2013). Metodika pro hodnocení environmentální výchovy pro starší školní věk a stř̌ední školy. Envigogika, 8(5). doi: 10.14712/18023061.414

ČS̆I (2017). Výběrové zjištováni výsledků žáků na úrovni 5. a 9. ročniků základních škol ve školním roce 2016/2017 - závěrečná zpráva. Praha: ČS̆I.

ČŠI (2018). Registr inspekčních zpráv. Praha: Ceská školní inspekce. Dostupné z https://www.csicr.cz/Dokumenty/Inspekcni-zprávy

ČSÚ (2018a). Správní obvod Žatec. Praha: Ceský statistický ústav. Dostupné z https://www.czso.cz/ csu/xu/spravni_obvod_zatec

CSUÚ (2018b). Statistická ročenka Ústeckého kraje. Praha: Ceský statistický ústav. Dostupné z https://www.czso.cz/ csu/statisticka-rocenka-usteckeho-kraje-2017

ČSÚ (2018c). Statistická ročenka České republiky. Praha: Český statistický ústav. Dostupné z https://www.czso.cz/csu/statisticka-rocenka-ceske-republiky

Daniš, P. (2013). Nové vymezení environmentální gramotnosti a návrh na její mezinárodní testování v PISA 2015. Envigogika, 8(3). doi: 10.14712/18023061.385

Gul, S. \& Yesilyurt, S. (2011). A study on primary and secondary school students' misconceptions about Greenhouse Effect (Erzurum Sampling). International Electronic Journal of Environmenal Education, 1(3), 193-202.

Hendl, J. (2015). Přehled statistických metod. Praha: Portál. 
Hollweg, K. S. Taylor, J. R., Bybee, R. W., Marcinkowski, T. J., McBeth, W. C. \& Zoido, P. (2011). Developing a framevork for assessing environmental literacy. Washington, DC: North American Association for Environmental Education.

Hromádka, Z. (2010). Životní prostředí ve vědomostech, postojích a jednání žáků druhého stupně základní školy. Disertační práce, Brno: Masarykova univerzita, Pedagogická fakulta.

Hungerford, H. R. \& Volk, T. L. (1990). Changing learner behavior through environmental education. The Journal of Environmental Education, 21(3), 8-21.

Hungerford, H. R., Volk, T., Wilke, R., Champeau, R., Marcikowski, T., May, T., Bluhm, W. \& McKeown-Ice, R. (1994). Environmental literacy Framework. Environmental Education Literacy Consorcium, University of South Illiois.

Hungerford, H. R., Volk, T. L., McBeth, W. C. \& Bluhm, W. J. (2009). Middle school environmental literacy survey. Carbondale, IL: Center for Instruction, Staff Development, and Evaluation.

Chytrý, V. \& Kroufek, R. (2017). Možnosti využití Likertovy škály - základní principy aplikace v pedagogickém výzkumu a demonstrace na prŕkladu zjištování vztahu člověka k přírodě. Scientia in educatione, 8(1), 1-16.

Jeffries, H., Stanisstreet, M. \& Boyes, E. (2001). Knowledge about the Greenhouse Effect: Have college students iproved? Research in Science and Technological Education, 19(2), 205-221. doi: 10.1080/02635140120087731

Kroufek, R. (2016). Environmentální gramotnost studentů Učitelství pro 1. stupeñ základni školy a možnosti jejîho zjištování [Disertační práce]. České Budějovice: Jihočeská univerzita, Pedagogická fakulta. doi: 10.13140/RG.2.1.3858.0724

Kuder, G. F. \& Richardson, M. W. (1937). The theory of the estimation of test reliability. Psychometrika, 2(3), 151-160. doi: 10.1007/BF02288391

Kulich, J. \& Dobiášová, M. (2003). Průzkum ekogramotnosti. Bedrník, př́loha časopisu, $1(2)$.

KÚ Ústeckého kraje (2011). Problémová analýza Ústeckého kraje. Ústí nad Labem: KÚ Ústeckého kraje.

Lane, S. (2014). Validity evidence based on testing consequences. Psicothema, 26(1), 127-135. doi: 10.7334/psicothema2013.258

Mareš, P., Rabušic, L. \& Soukup, P. (2015). Analýza sociálněvědních dat (nejen) $v$ SPSS. Brno: Masarykova univerzita.

McBeth, W. \& Volk, T. L. (2010). The national environmental literacy project:

A baseline study of middle grade students in the United States. The Journal of Environmental Education, 41(1), 55-67.

McBeth, W., Hungerford, H., Marcinkowski, T., Volk, T. L. \& Meyers, R. (2008). National environmental literacy assessment project: Year 1, national baseline study of middle grades students final research report. U.S. Environmental Protection Agency.

McBeth, W., Hungerford, H., Marcinkowski, T., Volk, T. L. \& Cifranick, K. (2011). The national environmental literacy assessment, phase two: Measuring the effectiveness of North American environmental education programs with respect to the parameters of environmental literacy. NOAA.

MŠMT (2017). Rámcový vzdělávací program pro základní vzdělávání. Praha: MŠMT. 
MPSV (2015). Projekt „Analýza sociálně vyloučených romských lokalit a absorpční kapacity subjektů pưsobicích v této oblasti“. Praha: MPSV. Dostupné

z https://www.esfcr.cz/mapa/int_us6_30.html

NAAEE (2010). Excellence in environmental education: Guidelines for learning (K-12). Washington: NAAEE.

Nastoulas, I., Marini, K. \& Skanavis, C., (2017). Middle school students environmental literacy assessment in Thessaloniki, Greece. In Anwar, S., Sergany, M. E. \& Ankit, A. (Eds.), Health and Environment Conference Proceedings (pp. 198-209). Dubai: Hamdan Bin Mohammed Smart University.

NÚV (2018). Environmentální výchova jako průřezové téma. Praha: Národní ústav pro vzdělávání. Dostupné z http://www.nuv.cz/file/3226/

Palmer, J. A. (2003). Environmental education in the 21st century. London: New York.

Pastorová, M. (Ed.). (2011). Doporučené očekávané výstupy. Praha: Výzkumný ústav pedagogický.

Penuel, W. R., Bienkowski, M., Gallagher, L., Korbak, C., Sussex, W., Yamaguchi, R. \& Fishman, B. J. (2006). GLOBE Year 10 evaluation: Into the next generation. Menlo Park, CA: SRI International.

Roth, C.E. (1992). Environmental literacy: Its roots, evolution, and directions in the 1990s. Columbus: ERIC Clearingouse for Science, Mathematics and Environmental Education.

Rios, J. \& Wells, C. (2014). Validity evidence based on internal structure. Psicothema, 26(1), 108-116. doi: 10.7334/psicothema2013.260

Sekaran, U. (1992). Research methods for business: A skill building approach. 2nd ed. New York, NY: Wiley.

Shapiro, S. S. \& Wilk, M. B. (1965). An analysis of variance test for normality (complete samples). Biometrika, 52(3 \& 4), 591-611. doi: 10.1093/biomet/52.3-4.591

Shoukri, M. M. \& Edge, V.L. (1996). Statistical methods for health sciences. Boca Raton: CRC Press.

Schovajsová, J. (2010). Současný stav environmentální výchovy na základních školách vybrané aspekty environmentální gramotnosti děti mladšího školního věku [Disertační práce]. Olomouc: Univerzita Palackého, Pedagogická fakulta.

Sireci, S. \& Faulkner-Bond, M. (2014). Validity evidence based on test content. Psicothema, 26(1), 100-107. doi: 10.7334/psicothema2013.256

Sireci, S. \& Padila, J. L. (2014). Validating assessments: Introduction to the special section. Psicothema, 26(1), 97-99. doi: 10.7334/psicothema2013.255

Stevenson, K. T., Peterson, M. N., Bondell, H. D., Mertig, A. G. \& Moore, S. E. (2013). Environmental, institutional, and demographic predictors of environmental literacy among middle school children. PLoS ONE, 8(3). doi: 10.1371/journal.pone.0059519

Stevenson, K. T., Carrier, S. J. \& Peterson, M. N. (2014). Evaluating strategies for inclusion of environmental literacy in the elementary school classroom. Electronic Journal of Science Education, 18(8), 1-17.

Svobodová, S. (2013). Vliv environmentální výchovy na úroveň ekogramotnosti žáků základních škol regionu Žatec [Diplomová práce]. Praha: ČZU. 
Svobodová, S. (2016). Vliv úrovně ekologické gramotnosti učitelů na úroveñ ekologické gramotnosti žáků vybraných škol v regionu Žatec [Diplomová práce]. Praha: UK.

Škoda, J. \& Doulík, P. (2007). Tvorba a hodnocení didaktických testů: cvičebnice pro studenty učitelství a účastníky kurzu DPS. Ústí nad Labem: UJEP.

Tavakol, M. \& Dennick, R. (2011). Making sense of Cronbach's alpha. International Journal of Medical Education, 2011(2), 53-55. doi: 10.5116/ijme.4dfb.8dfd

UNESCO (1975). The Belgrade Charter. A global framework for environmental education. Paris: UNESCO. Dostupné

z http://unesdoc.unesco.org/images/0001/000177/017772eb.pdf, cit. 6. 11. 2017.

UNESCO (1977). Intergovernmental conference on environmental education - Final report. United Nations.

Vacínová, M. \& Matějček, T. (2013). Intergenerational differences in personal relationship to nature. Envigogika, 8(2). doi: 10.14712/18023061.384

van Petegem, P. \& Blieck, A. (2006). The environmental worldview of children: a cross-cultural perspective. Environmental Education Research, 12(5), 625-635.

Volk, T. \& McBeth, B. (1998). Environmental literacy in the United States: What should be..., What is..., Getting from here to there. (A Report funded by the United States Environmental Protection Agency and submitted to the Environmental Education and Training Partnership, North American Association for Environmental Association.) Washington, DC: EETAP/NAAEE.

SiLvie SvobodovÁ, silviesvobodova74@seznam.cz

Univerzita Karlova, Pedagogická fakulta

Katedra biologie a environmentálních studií

Magdalény Rettigové 4, Praha, Ceská republika

Roman KroufeK, kroufek@gmail.com

Univerzita J.E. Purkyně, Pedagogická fakulta

Katedra preprimárního a primárního vzdělávání

Pausterova 1, Ústí nad Labem, Česká republika 


\section{Příloha Č. 1 - DotAZnÍK: 2. STUPEŇ ZŠ}

\section{MSELS}

Milá žákyně, milý žáku, pečlivým vyplněním tohoto anonymního dotazniku mi můžěs pomoci získat bližši informace o environmentálni gramotnosti žáků 2. stupně základni školy.

Dotazník obsahuje několik částí. Zodpovědně si přečti pokyny k jednotlivým částem. U každé položky vyber odpověd', která nejlépe vystihuje Tvưj názor, a uvedené pismeno zakroužkuj.

Děkuji za Tvé odpovědi.

\section{A. Demografické ÚdAJe}

1. Věk: $\square 12$ let $\square 13$ let $\square 14$ let $\square 15$ let a více

2. Ročník: $\square$ 6. ročník $\square$ 7. ročník $\square$ 8. ročník $\square$ 9. ročník

3. Pohlaví: $\square$ dívka $\square$ chlapec

4. Bydliště:

$\square$ méně než 100 obyvatel

$\square$ 100-1000 obyvatel

$\square$ 1000-10000 obyvatel

$\square$ 10000-100000 obyvatel

$\square$ více než 100000 obyvatel

5. Volný čas trávíš nejraději (můžeš zaškrtnout více variant):

$\square$ pobytem v přírodě

$\square$ u počítače

$\square$ pravidelnou návštěvou zájmové aktivity, uved’ jaké:

$\square$ sportováním

$\square$ jinak, uved’ jakým způsobem:

B. EnVironmentální ZnAlosti

(ČESKÝ PřEKLAD SCHOVAJSOVÁ 2010, UPRAVENO)

U každé otázky zakroužkuj jednu nejlepší odpověd’.

6. Opylování sladce vonící květiny s pestře zbarvenými okvětními plátky probíhá s největší pravděpodobností za pomoci:
(a) deště
(b) větru
(c) zahradníka
(d) hmyzu

7. Drobný pták sezobne motýla, který saje nektar z květu. Ptáka pak sežere jestřáb. Jedná se o př́íklad:
(a) vzájemně prospěšného soužití
(b) potravního řetězce
(c) soupeření
(d) přežití silnějšího 
8. Který z následujících vztahů je př́íkladem vztahu predátora (dravce) a kořisti?
(a) blecha kousne psa
(b) kos sezobne žížalu
(c) housenka sní list
(d) srna sní stéblo trávy, na němž sedí kobylka

9. Uhyne liška. Tím vznikne problém pro:
(a) blechy sající její krev
(b) králíka, který má nedaleko noru
(c) lišku ze sousedního teritoria
(d) zvíře, které loví na stejném území

10. Termiti se živí pouze dřevem, které ale nejsou schopni trávit. Drobné organismy obývající trávicí soustavu termitů ale dřevo tráví. Vztah mezi těmito organismy a termity lze vyjádřit takto:
(a) výhodný pro jedny a bez užitku pro druhé
(b) výhodný pro jedny a škodlivý pro druhé
(c) výhodný pro oba
(d) nevýhodný ani pro jedny

11. Kočka a had loví stejnou myš. Jaký je vztah mezi kočkou a hadem?
(a) jeden využívá druhého, ale neškodí mu
(b) soupeří spolu
(c) navzájem si pomáhají
(d) jeden se snaží sežrat druhého

12. Kdyby na Zemi neexistovali rozkladači (rozkladné organismy), co by se stalo?
(a) Odumřelé části rostlin a mrtvá zviřrata by se nestávaly součástí půdy.
(b) ̌rada lidských chorob by vymizela.
(c) Lidé by měli $\mathrm{k}$ dispozici daleko více masa.
(d) Téměř nic by se nezměnilo.

13. Travnatá pláň se promění v poušte. Co se nejpravděpodobněji stane se zviřraty, která na pláni žijí?
(a) Většina z nich odejde nebo uhyne.
(b) Budou se více množit, aby přežila.
(c) Ta, co se živí trávou, přejdou na jinou potravu.
(d) Řada z nich předá potomkům rysy, které jejich mlád’atům pomohou přežít $\mathrm{v}$ poušti.

14. Skupina lidí zavedla ve státním lese program na ochranu vysoké zvěře (jeleni, srny, daňci atd.). V jeho rámci začali lovit vlky. O deset let později už v lese nebyli žádní vlci. Za dalších několik let, kdy vlci už v lese nežili, bylo v lese daleko více vysoké než kdy předtím. Potom náhle téměř všechna vysoká zvěř zmizela. Lidé, kteří chtěli chránit vysokou zvěř, nevěděli, že:
(a) Vysoká se dožívá jen několika let.
(b) Požáry vyhubí tolik vysoké.
(c) Jiná zvířata sežerou vysoké zvěři tolik potravy.
(d) Vysoká zvěř spotřebuje veškerou potravu a řada jedinců uhyne. 
15. Původním zdrojem energie pro všechny živé organismy je:
(a) Slunce
(b) voda
(c) půda
(d) rostliny

16. Tělo uhynulého ptáka se rozkládá. Co se stane s energií uloženou v jeho těle?
(a) Nestane se s ní nic. Jakmile pták uhyne, energie přijde vniveč.
(b) Projde organismy, které rozkládají mrtvé tělo.
(c) Zničí ji sluneční záření.
(d) Pták energii spotřeboval, když byl naživu.

17. Králík sní kukuřici. Energie z kukuřice přejde do králíka. Další den sežere králíka liška. Liška získá z kukuřice jen nepatrné množství energie. Proč?
(a) Králík nedokáže trávit kukuřici.
(b) Králík již kukư̌ici strávil.
(c) Kukuřice není příliš energeticky vydatná.
(d) Králík již většinu energie z kukuřice spotřeboval.

18. Většina kyslíku v atmosféře pochází z:
(a) hmyzu
(b) rostlin
(c) půdy
(d) Slunce

19. Jakým způsobem mohou lidé získat z tuny rostlin nejvíce energie?
(a) Kdyby rostlinným materiálem nakrmili hmyz, ten dali sežrat rybám a poté sami snědli ryby.
(b) Lidé by snědli rostliny.
(c) Nakrmili by rostlinami dobytek a ten pak snědli.
(d) Nakrmili by rostlinami ryby a pak ryby snědli.

20. Poté, co živé organismy uhynou, rozloží se. Výsledkem tohoto procesu je, že živiny:
(a) se vrátí zpět do životního prostředí a projdou dalším cyklem
(b) jsou zničeny bakteriemi
(c) se přemění na kyslík a vodní páru
(d) se vypaří vlivem tepla vyprodukovaného při rozkladu

21. Který z následujících procesů je součástí vodního koloběhu?
(a) eroze
(b) př́liv oceánů
(c) vypařování
(d) rozklad 
22. Dojde ke znečištění životního prostředí a následně k úhynu velkého množství hmyzu. Jak se to může projevit na ekosystému?
(a) Rostliny nejsou poškozené, takže ekosystém to neovlivní.
(b) Dojde k poškození části ekosystému, což ovlivní celý ekosystém.
(c) Uhyne pouze hmyz, takže ostatní živočichové zůstanou zdraví.
(d) Většina zviŕrat se živí rostlinami, takže ekosystém to př́iliš nezasáhne.

\section{EnVironmentální Postoje \\ (ČESKÝ PřEKLAD SvOBOdovÁ, KROUfEK)}

U každé otázky zakroužkuj odpověd', která nejpřesněji vystihuje tvůj postoj k př́rodě a životnímu prostředí (co si myslíš o př́rodě a životním prostředí).

23. Byl(a) bych ochotný(á) přestat kupovat některé výrobky, abych chránil(a) zvírata.
(a) souhlasím
(b) spíše souhlasím
(c) nejsem si jistý
(d) spíše nesouhlasím
(e) nesouhlasím

24. Nebyl(a) bych ochotný(á) šetřit energie nižším používáním klimatizace.
(a) souhlasím
(b) spíše souhlasím
(c) nejsem si jistý
(d) spíše nesouhlasím
(e) nesouhlasím

25. Abych šetřil(a) vodou, byl(a) bych ochotný(á) snížit při koupání její množství.
(a) souhlasím
(b) spíše souhlasím
(c) nejsem si jistý
(d) spíše nesouhlasím
(e) nesouhlasím

26. Nevěnoval(a) bych vlastní peníze na ochranu přírody a životního prostředí.
(a) souhlasím
(b) spíše souhlasím
(c) nejsem si jistý
(d) spíše nesouhlasím
(e) nesouhlasím

27. Abych sní̌il(a) znečištění ovzduší, chodil(a) bych více pěšky.
(a) souhlasím
(b) spíše souhlasím
(c) nejsem si jistý
(d) spíše nesouhlasím
(e) nesouhlasím 
28. Netřídil(a) bych odpad kvůli recyklaci.
(a) souhlasím
(b) spíše souhlasím
(c) nejsem si jistý
(d) spíše nesouhlasím
(e) nesouhlasím

29. Byl(a) bych ochotný(á) věnovat vlastní peníze na pomoc při ochraně divokých zvírat.
(a) souhlasím
(b) spíše souhlasím
(c) nejsem si jistý
(d) spíše nesouhlasím
(e) nesouhlasím

30. Abych šetřil(a) energiemi, byl(a) bych ochotný(á) používat úspornější žárovky.
(a) souhlasím
(b) spíše souhlasím
(c) nejsem si jistý
(d) spíše nesouhlasím
(e) nesouhlasím

31. Abych šetřil(a) vodou, byl(a) bych ochotný(á) vypínat vodu při čištění zubů.
(a) souhlasím
(b) spíše souhlasím
(c) nejsem si jistý
(d) spíše nesouhlasím
(e) nesouhlasím

32. Byl(a) bych ochotný(á) předávat environmentální informace o místním problému.
(a) souhlasím
(b) spíše souhlasím
(c) nejsem si jistý
(d) spíše nesouhlasím
(e) nesouhlasím

33. Byl(a) bych ochotný(á) písemně požádat ostatní, aby pomáhali snižovat znečištění.
(a) souhlasím
(b) spíše souhlasím
(c) nejsem si jistý
(d) spíše nesouhlasím
(e) nesouhlasím 
34. Byl(a) bych ochotný(á) přesvědčovat ty, kteří nerecyklují, aby recyklovat začali.
(a) souhlasím
(b) spíše souhlasím
(c) nejsem si jistý
(d) spíše nesouhlasím
(e) nesouhlasím

\section{ENVIRONMENTÁLNí JEDNÁNí}

\section{(ČESkÝ PřEKLAD SvOBOdovÁ, Kroufek)}

U každé otázky zakroužkuj odpověd’, která nejpřesněji vystihuje, co děláš pro př́rodu a životní prostředí.

35. Nezajímám se o problémy znečištění.
(a) souhlasím
(b) spíše souhlasím
(c) nejsem si jistý
(d) spíše nesouhlasím
(e) nesouhlasím

36. Mluvím se svými rodiči o tom, jak lze pomáhat při řešení environmentálních problémů.
(a) souhlasím
(b) spíše souhlasím
(c) nejsem si jistý
(d) spíše nesouhlasím
(e) nesouhlasím

37. Při mytí zubů vypínám vodu, abych s ní více šetřil.
(a) souhlasím
(b) spíše souhlasím
(c) nejsem si jistý
(d) spíše nesouhlasím
(e) nesouhlasím

38. Nepotřebuji-li doma svítit, zhasínám, abych šetřil(a) energiemi.
(a) souhlasím
(b) spíše souhlasím
(c) nejsem si jistý
(d) spíše nesouhlasím
(e) nesouhlasím

39. Požádal(a) jsem rodiče, aby nekupovali výrobky ze zvířecích kožešin.
(a) souhlasím
(b) spíše souhlasím
(c) nejsem si jistý
(d) spíše nesouhlasím
(e) nesouhlasím 
40. Požádal(a) jsem svou rodinu, aby některé věci používali opakovaně.
(a) souhlasím
(b) spíše souhlasím
(c) nejsem si jistý
(d) spíše nesouhlasím
(e) nesouhlasím

41. Ptám se i ostatních, co můžu udělat já pro snižování znečištění.
(a) souhlasím
(b) spíše souhlasím
(c) nejsem si jistý
(d) spíše nesouhlasím
(e) nesouhlasím

42. Často si čtu o př́rodě a životním prostředí.
(a) souhlasím
(b) spíše souhlasím
(c) nejsem si jistý
(d) spíše nesouhlasím
(e) nesouhlasím

43. Vodovodní kohoutek nechávám téct pouze tehdy, je-li to nezbytně nutné.
(a) souhlasím
(b) spíše souhlasím
(c) nejsem si jistý
(d) spíše nesouhlasím
(e) nesouhlasím

44. Dokud se rozhoduji, co si vyndám z lednice, nechávám její dveře zavřené.
(a) souhlasím
(b) spíše souhlasím
(c) nejsem si jistý
(d) spíše nesouhlasím
(e) nesouhlasím

45. Poblíž svého domova vyvěšuji ptačí budky nebo krmítka.
(a) souhlasím
(b) spíše souhlasím
(c) nejsem si jistý
(d) spíše nesouhlasím
(e) nesouhlasím

46. Věci v domácnosti netřídím k jejich recyklování (opakovanému využití).
(a) souhlasím
(b) spíše souhlasím
(c) nejsem si jistý
(d) spíše nesouhlasím
(e) nesouhlasím 
V několika následujících otázkách se tě budeme ptát na míru tvé citlivosti $\mathrm{k}$ přírodě a životnímu prostředí, tedy na pocity, které prožíváš směrem k přírodě a životnímu prostředí.

U každé otázky zakroužkuj odpověd', která nejpřesněji vystihuje tvé pocity/vnímání.

47. Tvůj vztah k přírodě a životnímu prostředí je:
(a) velmi silný
(b) silný
(c) středně silný
(d) slabý
(e) minimální

48. Vztah tvé rodiny k přírodě a životnímu prostředí je:
(a) velmi silný
(b) silný
(c) středně silný
(d) slabý
(e) minimální

49. Jak často trávíš rodinnou dovolenou či výlety ve volné přírodě?
(a) velmi často
(b) často
(c) průměrně
(d) občas
(e) nikdy

50. Jak často lovíš nebo rybaříšs?
(a) velmi často
(b) často
(c) průměrně
(d) občas
(e) nikdy

51. Jak často se věnuješ aktivitám typu procházky, turistika, cyklistika, potápění nebo kanoistika?
(a) velmi často
(b) často
(c) průměrně
(d) občas
(e) nikdy 
52. Jak často se věnuješ pozorování ptáků nebo fotografování př́írody?
(a) velmi často
(b) často
(c) průměrně
(d) občas
(e) nikdy

53. Jak často se účastníš kempování v rámci zájmové organizace (např. sportovní oddíl, kroužek, skaut atd.)?
(a) velmi často
(b) často
(c) průměrně
(d) občas
(e) nikdy

54. Jak často trávíš čas v přírodě sám, nikoli jako člen nějaké skupiny?
(a) velmi často
(b) často
(c) průměrně
(d) občas
(e) nikdy

55. Jak často se bavíš četbou knih či časopisů o přírodě nebo životním prostředí?
(a) velmi často
(b) často
(c) průměrně
(d) občas
(e) nikdy

56. Jak často se bavíš sledováním pořadů o přírodě nebo životním prostředí?
(a) velmi často
(b) často
(c) průměrně
(d) občas
(e) nikdy

57. Myslíš si, že tví učitelé mají pozitivní vztah k přírodě a životnímu prostředí?
(a) souhlasím
(b) spíše souhlasím
(c) nejsem si jistý
(d) spíše nesouhlasím
(e) nesouhlasím 
F. VZTAH K ŽIVOTNÍMU PROSTŘEdí

(ČESKÝ PřEKLAD SVOBOdOVÁ, KROUfEK)

U každé otázky zakroužkuj odpověd’, která nejpřesněji vystihuje míru tvého souhlasu.

58. Miluji př́rodu a životní prostředí.
(a) zcela souhlasím
(b) spíše souhlasím
(c) neutrální postoj
(d) spíše nesouhlasím
(e) zcela nesouhlasím

59. Nenávidím přírodu a životní prostředí.
(a) zcela souhlasím
(b) spíše souhlasím
(c) neutrální postoj
(d) spíše nesouhlasím
(e) zcela nesouhlasím

NYNÎ MÁŠ DOTAZNÍK VYPLNĚNÝ A MƯŽEŠ ODLOŽIT PSACÍ POTŘEBY. DĚKUJI ZA ÚČAST! 